\section{Anthropological Studies in India}

IN view of the important part which will be played by racial, religious and social questions in relation to administration and government in the India of the future, considerable interest is attached to a brief survey of the work in anthropology which has been, and is now being, done in India by Rai Bahadur L. K. Ananthakrishna Iyer, chairman of the Board of Higher Studies in Anthropology of the University of Calcutta and the author of a number of wellknown works on Indian anthropology, which appears in Current Science of January 1934. He points out that it is only in the last fifteen years that the vast mass of anthropological material offered by India has begun to be utilised systematically. The School of Anthropology in the University of Calcutta was organised in 1921, and the University is now unique in prescribing the subject for the M.A. and M.Sc. examinations. The students also have the advantage of an annual course of practical instruction in the field in various parts of Bengal and Chota Nagpur, when both anthropometry and cultural anthropology are studied.

THE anthropological work of the University is supplemented in Calcutta by that of the Indian Museum, where there is a well-equipped laboratory, and research work is also earried on. Much of this research has already been embodied in important monographs. Reference is also made to the work of Dr. J. H. Hutton in Assam and to that of Sarat Chandra Roy, editor of "Man in India". On the west coast, the only institution concerned with anthropology is the Anthropological Society of Bombay; and the author expresses regret that Madras, with one old and two infant universities, has taken so little advantage of its opportunities for anthropological research. In Mysore, the University has revived the Ethnographic Survey of the State, and the fourth and final volume of its report is now in preparation for publication. The work of the Indian Science Congress is also noted. The author concludes by deploring the fact that while there are many regions in India unexplored anthropologically, the workers are few. He urges that a band of young men should be trained to collect material in these unexplored fields.

\section{Agricultural Education in New Zealand}

Agricultural research in New Zealand has a staunch friend in the Governor-General, Lord Bledisloe, who, having a lifelong acquaintance with British agriculture, is peculiarly fitted to estimate the value to the farming community of such agencies as the New Zealand Department of Scientific and Industrial Research and the Cawthron Institute. In a recent address to the students of Wellington College, New Zealand, on the new needs of education, he referred to the appointment of a former student, Theodore Rigg, to the directorship of the Institute, "an organization notable throughout the Empire for the thoroughness, accuracy, and economic value of its agricultural researches". Touching on the question of the careers for which a college training offers a suitable preparation, he stressed the claims of the rural population of a Dominion in which farming is the greatest industry to leadership such as a college graduate might aspire to. He added point to his observations by revealing that it was considerations such as these which induced the Rhodes scholar. ship selection committee to select, for the first time in the history of the Trust, a young agricultural scientific worker for appointment to one of these scholarships.

\section{Investigations in the Stratosphere}

THFre are now two bodies in Russia intent on surveying the scientific and other possibilities of the upper atmosphere. They are the Society for Aviation and Chemical Warfare, with outside experts and with M. Dubenski, assistant director of the Military Aviation Academy, as chairman of the commission, and a more civilian type of composite body drawn from the Leningrad Institute of Aerology, the Radio Institute and the Central Geophysical Laboratory. The former organisation was responsible for the successful flight of Stratostat USSR, piloted by M. Prokofiev last September, as well as that ending in disaster on January 30 this year. If one can judge from the reports from Russian newspapers, these two schools are sharply divided on the question of manned and unmanned balloons respectively. The military organisation, the programme of which is the study of ultra-violet solar radiation and atomic disintegration by cosmic rays, is concentrating its attention on shock-absorbers, gliders, parachutes, etc., in order to safeguard future crews from disaster. The civil body, however, is specialising upon further improvements in automatic registering devices to be attached to balloonets after the manner of Regener's, whose work with these down to a pressure of $22 \mathrm{~mm}$. (about 28 kilometres up) has not yet been superseded. The new device consists of a string of two or three such elastic balloonets each about 2 metres in diameter on the ground, filled with hydrogen for carrying the selfrecording devices. A trial has already been made with one such balloonet. This reached a maximum altitude of 18.6 kilometres and was followed during its ascent by theodolite observations. It automatically transmitted radio signals of pressure, temperature and hygrometric data on a wave-length of 25 metres. Unfortunately, the apparatus has been lost. In a new apparatus which was to be ready by the end of March, there were to be added cosmic ray intensity and gas analysis transmissions and a camera. This work of the Institute of Aerology is a very laudable enterprise and the results will be awaited with interest.

\section{Sydney Harbour Bridge}

AmoNg the recently published abstracts of papers to be discussed by the Institution of Civil Engineers are four relating to the design, construction and calculations of the great arch bridge over the harbour a.t Sydney, New South Wales. The papers, Nos, 4904, 4922, 4923 and 4946, are by Mr. R. Freeman, Mr. L. Ennis, Mr. J. F. Pain, Mr. G. Roberts and Dr. J. J. C. Bradfield, and the discussion will be held on April 10. 
The bridge, which took a little more than eight years to complete, cost $£ 4,248,000$. It consists of a main span of $1,650 \mathrm{ft}$. with a clearance of $170 \mathrm{ft}$. over the central $300 \mathrm{ft}$. of span, and ten approach spans. It accommodates a roadway $57 \mathrm{ft}$. wide, four railway tracks and two footways. The prineipal parts of the main-span truss are of silicon steel with a modulus of elasticity of $30,500,000 \mathrm{lb}$. per sq. in. Analytical methods of calculation were used, arithmetical processes being carried out by calculating machines. Calculations were required for the following combinations of loads : dead load, Jive load and impact, horizontal force, centrifugal force, wind loads and temperature variation. Of the total weight of the main truss material, the proportions attributable to various loads are as follows: dead weight of arch, 35 per cent ; dead weight of deck, 23 per cent ; live load and impact, 26 per cent; wind, 8 per cent; horizontal force, 2 per cent ; and temperature, 6 per cent. Tests on model members were made by means of a testing machine of 1,250 tons capacity, capable of dealing with tension and compression specimens up to $50 \mathrm{ft}$. long and bend test specimens $20 \mathrm{ft}$. long. Tests of the arch after completion indicated a span $\frac{3}{4}$ in. in excess of $1,650 \mathrm{ft}$., a difference partly due to unavoidable errors of survey and possibly partly caused by shrinkage of the concrete below the bearings. The bridge was erected by Messrs. Dorman, Long and Co., of Middlesborough.

\section{The Indian Antiquary}

WITH the December issue, which, through labour troubles, has only just become available in Great Britain, the Indian Antiquary ceases publication. The demise of this valuable periodical will be greatly regretted by all who are interested in Indian studies. For more than sixty years it has served as a medium of publication for original communications of the highest standard of scholarship, dealing with the ethnology, archæology, history, linguistics, folk-lore and religions of India. The Indian Antiquary was founded by the late Dr. J. Burgess in 1872 and later was acquired by the late Sir Richard Temple as his sole property. Under his editorship-he was editor-in-chief for forty-six out of the fifty-one years of his connexion with it-the services of the Indian Antiquary to the cultural history of India were incalculable. Sir Richard Temple's wide knowledge of orjental subjects made him an ideal editor of a journal of this type, not merely because of his own numerous contributions to its pages, but also for the stimulus and assistance he was able to give to the studies of others. As one result of his influence may be mentioned Epigraphia Indica, the official record of epigraphic work in India, which was a direct outgrowth of work initiated by the Indian Antiquary. In 1924 Sir Richard Temple transferred his interest in the journal to a small private company, and the Royal Anthropological Instjtute assumed responsibility for its publication. Sir Richard Temple retained the editorship, at first in association with Mr. S. M. Edwardes, and after his death in 1927 with Mr. C. E. A. W. Oldham, who became editor-in-chief on Sir Richard's death in 1931. Owing to financial conditions the Royal Anthropological Institute felt compelled to sever its connexion with the Indian Antiquary in 1932 and during the past year it has been carried on by the editor in order to complete publication of matter in hand.

\section{Protection of Power-Transmission Plant from Lightning}

A serres of articles on lightning by J. F. Shipley which is being reprinted in Distribution of Electricity, a paper published by W. T. Henley's Telegraph Works Co., gives a résumé of what has been accomplished in recent years in protecting transmission lines and engineering plant connected with them from damage from lightning. The effect of a lightning flash on a transmission line is to puncture the insulators or make them flash over, sometimes causing a short circuit which shuts down the supply. During the last forty years a very large number of devices have been employed to protect the lines, such as air-gaps, water-jets, oxide films, etc. These have been found only partially effective. The ideal arrester would be some link between the line and earth which would have infinite resistance at the normal pressure, but when for any reason that pressure increased by 10 or 20 per cent, the resistance should become practically zero, thus furnishing the impulsive rush of electricity with a safe path to earth. A recent device consists of a solid block of a material consisting of conducting particles of metallic oxide diffused in a baked clay which is microscopically porous. It is similar to porcelain in texture and mechanical strength and normally has almost infinite resistance. As soon as the electrical pressure across a block of it rises above a definite value its resistance decreases at a very rapid rate. If we double the voltage, the current it will pass increases more than twelve times. The material seems to have two names, 'thyrite' and 'ocelit'. As it is an artificial product and can be accurately controlled, it looks as if a real step forward has been made in the design of these arresters, or 'safety-valves' as they are often called.

\section{Electric Waxing of Floors}

Helios, a German electrical trade journal printed in Leipzig, gives descriptions in three parallel columns in German, French and English respectively of the latest electrical devices. In the issue for November 19 an interesting description is given of tests on an electric floor-waxing device, with and without a suction apparatus for the simultaneous collection of dust. The tests were carried out in the laboratories of several universities as well as in commercial test rooms. When the suction device was used there was no appreciable change in the percentage of dust in the air caused by the whirling of the waxing apparatus. When no suction device was employed the percentage of dust in the air increased as much as seven to eight times the normal quantity. In this case the dust on the floor was whirled upwards by the waxing machine. With the suction device it is not necessary to clean the room so often and there is no need to have a special vacuum cleaner. The dust which settles on furniture prolongs the work of cleaning, and certain works of art are damaged, while it is 